University of Nebraska - Lincoln

DigitalCommons@University of Nebraska - Lincoln

Faculty Publications, Department of Psychology

Psychology, Department of

$1-1-2000$

Precious Little Guidance: Jury Instruction on Damage Awards

Edith Greene

University of Colorado at Colorado Springs, egreene@uccs.edu

Brian H. Bornstein

University of Nebraska-Lincoln, bbornstein2@unl.edu

Follow this and additional works at: https://digitalcommons.unl.edu/psychfacpub

Part of the Psychiatry and Psychology Commons

Greene, Edith and Bornstein, Brian H., "Precious Little Guidance: Jury Instruction on Damage Awards" (2000). Faculty Publications, Department of Psychology. 295.

https://digitalcommons.unl.edu/psychfacpub/295

This Article is brought to you for free and open access by the Psychology, Department of at DigitalCommons@University of Nebraska - Lincoln. It has been accepted for inclusion in Faculty Publications, Department of Psychology by an authorized administrator of DigitalCommons@University of Nebraska - Lincoln. 


\title{
Precious Little Guidance: Jury Instruction on Damage Awards
}

\author{
Edith Greene, Department of Psychology, University of Colorado at Colorado Springs \\ Brian Bornstein, Department of Psychology, Louisiana State University
}

\begin{abstract}
Jury instructions on damage awards are notoriously vague and ambiguous. As a result, awards are sometimes unexpected and seemingly illogical. In this article, the authors argue that jury instructions regarding damages are vague because the law of damages itself is purposefully ambiguous - allowing particularized justice across a variety of different circumstances. The authors review research on comprehension and application of substantive jury instructions related to damages and on procedural variations at trial (e.g., use of preinstruction, bifurcation, blindfolding jurors to various issues, special verdict forms, caps on damages, and instruction revision) that impact the substantive instructions that jurors receive from the judge. They comment on attempts at reforming jury instructions regarding damages and conclude that jurors' decision making on this difficult and emotional issue could be made more predictable by careful reforms at the trial level.
\end{abstract}

I was under the impression we'd have guidelines. I feel we were thrown in a box and had to come out with a number. (Anonymous juror quoted by Vidmar, 1995, p. 243)

A juror serving in a North Carolina medical malpractice case expressed this sentiment. She and fellow jurors heard evidence at trial that a 28 -year-old plaintiff suffered a peritoneal infection and permanent brain injury after undergoing cesarean surgery. During the trial, the jury was provided with evidence of medical bills resulting from her injury that amounted to several thousands of dollars. The defense attorney argued vehemently that the plaintiff's injuries were not caused by the defendant's actions but then said any award to which the plaintiff was entitled should be small because the hospital and doctors had already paid her medical expenses. In his charge to the jury on damages, the judge informed the group that they should consider the amount of compensation the plaintiff should have as well as an amount for the husband's claim of loss of consortium. He further cautioned them to determine an award based solely on the evidence and instructed them that the amount should be fair, just, and reasonable and not determined by sympathy.

The jury deliberated for $3.5 \mathrm{hr}$, after which they returned a verdict of $\$ 850,000$ along with strongly worded complaints about the ambiguity involved in their assigned task. Several members of the jury apparently felt that doing their duty "was difficult for all of us."

Corresponding author: Edith Greene, Department of Psychology, University of Colorado, Colorado Springs, Colorado 80933; Email egreene@mail.uccs.edu.

Brian Bornstein is now at the Department of Psychology, University of Nebraska-Lincoln. 
Why is the determination of damages so difficult? And what role do judicial instructions play in the process? Do they elucidate the jury's assignment? Do they further obscure it? Or, perhaps, are the instructions so imprecise as to be unhelpful and therefore essentially ignored?

A civil jury's assignment is difficult because that jury must undertake various tasks and use different sources of information and decision rules to complete these tasks. For example, jurors in a product liability case must first decide if the product in question was defective. To do so, they would rely on industry standards and policies. They must also determine whether any alleged defect in the product caused injury to the plaintiff. Expert medical testimony is often elicited on the topic of causation.

If jurors determine that the plaintiff has indeed proven these issues by a preponderance of the evidence, they turn to their next set of tasks - deciding whether the plaintiff is entitled to damages and in what amount. First, they are instructed to award the plaintiff compensatory damages insofar as these damages have been proved by a preponderance of the evidence. Here, they are to assess the economic and noneconomic losses to the plaintiff that were caused by use of the defective product. Next, they may have the option to award punitive damages. Here, they are instructed to focus not on the plaintiff's condition but instead on the conduct and wealth of the defendant manufacturer. They are instructed to determine whether the plaintiff has proven (often by a different standard of proof, i.e., by clear and convincing evidence) that the defendant's conduct was willful and wanton and, if so, to impose a punitive damages award that will punish and deter the defendant. Obviously, each of these multiple decisions involves a complex judgment in and of itself, and each relies on a unique set of evidentiary information.

This article focuses on the difficult tasks of determining damages and, in particular, on the role of jury instructions in assisting jurors to make those decisions. Following a brief primer on damage awards, we address the issue of the vagueness of jury instructions and the resulting difficulties that may cause for jurors charged with assessing damages. We review research on comprehension and application of substantive jury instructions related to damages and on procedural variations at trial (e.g., preinstruction, bifurcation) that impact the instructions that jurors receive from the judge. We describe attempts at reforming jury instructions, particularly with regard to punitive damages. Finally, we conclude that civil jurors' occasional failings may be directly related to the vagueness of their charge and that their verdicts will become more predictable and legally appropriate if certain reforms were made at trial and if their directives could be made clearer.

\section{A Primer on Damage Awards}

Damages fall into three categories: economic, noneconomic, and punitive. The first two types constitute compensatory damages, which are generally intended to return the plaintiff to preinjury levels of functioning or, if that is not possible, to make up for the loss and to right the wrongs inflicted by the defendant. If the jurors determine that the defendant is liable, they are then expected to fully compensate the plaintiff for his losses. 
Economic damages refer to the financial costs incurred by the plaintiff as a result of the injury. These losses include past and future income and past and future medical expenses. In theory, these losses should be relatively easy for an economist or accountant to quantify. In practice, however, debate over these estimates is often contentious. The calculations must take into account forecasts about future medical care needs, available job opportunities, and projected life expectancies. In addition, because jury damage awards are typically discounted to present value (the plaintiff is awarded a certain amount now that will, over time, grow to equal the amount the jury has deemed appropriate), there may be rancorous debate about future prospects for inflation and interest rates.

Noneconomic damages are awarded to compensate the plaintiff for bodily harm, including pain and disfigurement; emotional distress, including fear, anxiety, and depression; and loss of enjoyment of life, including limitations on lifestyle options. These losses, generally referred to as pain and suffering, entail obvious social and psychological components (Wissler, Evans, Hart, Morry, \& Saks, 1997).

Plaintiffs can also request punitive damages. This award is designed to punish the defendant for egregious conduct and to deter the defendant and others from engaging in similar conduct in the future. Jurors are generally instructed they may award punitive damages if they find that the defendant acted in a willful or wanton manner.

In a typical civil negligence case, the jury will hear evidence about many of these issues. Experts may be called to offer opinions about the medical and economic circumstances of the plaintiff and, in actions for punitive damages, about the financial status of the defendant. The defense may counter with its own experts and arguments (Vidmar, 1995). The judge then instructs jurors that if they find the defendant liable, they may assess damages. They are further instructed to reach a verdict that is "fair and reasonable" in light of the evidence. Not surprisingly, civil jurors report that determining damages is a more difficult task than deciding on liability (Diamond, 1993), and they lay blame on the minimal guidance they receive from the judge.

\section{Ambiguity of Jury Instructions on Damage Awards}

Jury instructions on damage awards are notoriously vague and ambiguous. Consider the following example of a typical instruction on assessing damages in a personal injury case:

If you find in favor of the plaintiff, you shall award as actual damages, insofar as they have been proved by a preponderance of the evidence and insofar as they were caused by the defendant's negligence, an amount which will reasonably compensate the plaintiff for his injuries, if any. In determining such damages, you shall consider the following:

1. Any noneconomic losses or injuries incurred to the present time, or which will probably be incurred in the future, including: pain and suffering; inconvenience; emotional stress; impairment of the quality of life; and

2. Any economic losses incurred to the present time, or which will probably be incurred in the future, including: loss of earnings or impairment of earning 
capacity; reasonable and necessary medical, hospital and other expenses. (Colorado Jury Instructions 3d: Civil, 1989)

Jurors are typically informed about the components of economic damages (including past and future economic losses and past and future noneconomic losses), but they are not typically instructed on the definitions of various terms (e.g., pain and suffering, emotional stress), about how to consider and weigh these components, or about how to translate these components into an aggregate award. Further, they are instructed to discount the assessed damages to present value but are not told explicitly how to do this, nor are they told how to evaluate any conflicting expert testimony related to damages.

Instructions on punitive damages, in particular, have been criticized for their ambiguity. Courts usually admonish jurors simply to assess punitive damages sufficient to punish and deter and, in so doing, to consider the character of the defendant's conduct and the defendant's wealth. Some courts supplement these instructions with criteria used by appellate courts in posttrial review of awards. These considerations include the requirement that the award bear some reasonable relationship to compensatory damages, that it not bankrupt the defendant, and that the jury not be motivated by passion or prejudice. It is unclear to what extent jurors consider these factors. Here is a typical instruction on punitive damages:

\begin{abstract}
If you find in favor of the plaintiff and award her actual damages, then you shall consider whether exemplary (or punitive) damages should be assessed against the defendant. If you find beyond a reasonable doubt ${ }^{1}$ that the injury complained of was attended by circumstances of willful and wanton conduct, then in addition to actual damages, you may also assess a reasonable sum as exemplary damages. Exemplary damages, if assessed, are to be assessed as punishment for the defendant, and as an example to others. (Colorado Jury Instructions 3d: Civil, 1989)
\end{abstract}

Suggesting that arbitrariness, caprice, passion, bias, and even malice can replace reasoned judgment and law as the basis for jury decision making about punitive awards, Justice Sandra Day O'Connor has noted that juries receive only "vague and amorphous guidance" about punitive damages (TXO Prod. Corp. v. Alliance Resources Corp., 1993, p. 474). Justice William Brennan voiced a similar concern:

\begin{abstract}
Without statutory (or at least common-law) standards for a determination of how large an award of punitive damages is appropriate in a given case, juries are left largely to themselves in making this important and potentially devastating decision ... The typical instructions given to jurors, advising them to consider the character and wealth of the defendant and the nature of the defendant's conduct, provide guidance that is scarcely better than no guidance at all. (Browning-Ferris Industries, Inc. v. Kelco Disposal, Inc., 1989, p. 281)
\end{abstract}

Commentators note other problems with instructions related to punitive damages. Some suggest that juries frequently misunderstand their instructions in complicated cases (where claims for punitive damages are more likely to arise) and experience

\footnotetext{
${ }^{1}$ The standard for proving punitive damages is lower in other jurisdictions (e.g., by a preponderance of the evidence or by clear and convincing evidence).
} 
such confusion that they neglect their instructions altogether and attempt to reach a verdict on the basis of their common sense ("Developments in the Law," 1997). Others believe that because a typical punitive damages case involves a series of complicated issues, even juries that understand their instructions may nonetheless get it wrong because they do not correctly assess the social costs and benefits of the defendant's conduct. Melsheimer and Stodghill (1994) have reasoned that by providing juries with broad discretion and little guidance, the common law allows jurors' biases and judgmental deficiencies to operate in an unrestrained manner.

The problem may not reside solely with the jury instructions themselves, however. Instructions about damages are notoriously vague because the law of damages is notoriously and purposefully vague. In most jurisdictions, standards for defining when a certain kind of damage award (e.g., for pain and suffering, loss of consortium, or punitive damages) is appropriate have not been articulated, in part because it is difficult to identify the particular circumstances in which these damages may be relevant. Consequently, this vagueness may be an inherent (and, in fact, necessary) aspect of standards for determining damage awards. Unfortunately, it may leave jurors questing for more direction.

There are, of course, advantages that inhere in vague standards. Such ambiguity allows the trier of fact to apply the doctrine flexibly and, theoretically, to achieve justice based on the individualized facts of a particular case. On the other hand, imprecise standards may allow jurors to subvert justice by relying on their biases, prejudices, and whims. Further, vague direction may legitimate fused decision making by allowing discussions of liability to merge with damage award determinations (Bornstein, 1998). In other words, lacking clear guidance on what evidence they can legitimately use to assess damages, jurors may factor elements of the evidence on liability into their calculation of damages (Greene, Johns, \& Smith, in press). So, along with the benefits that issue from indefinite standards come difficulties for jurors in placing monetary values on losses that are often intangible and difficult to assess.

\section{Substantive Instructions Versus Procedural Variations Related to Instructions}

We make a distinction here between substantive jury instructions and procedural variations related to those jury instructions. The former category includes instructions that express the intent of the statute, that are typically contained in a set of model jury instructions, and that the judge actually delivers to the jury at the close of the trial. Little research has evaluated the effectiveness or impact of substantive instructions on damage awards.

Procedural variations related to the instructions, on the other hand, involve procedural decisions (e.g., about preinstruction, bifurcation, blindfolding the jury to various issues, use of a special verdict form, capping damage awards at a certain amount) made by the judge during the course of the trial with input from counsel. These procedural issues and resultant instructions influence how jurors receive the case, what substantive instructions they hear, and what decisions they are to provide. For example, if a judge decides to bifurcate evidence related to compensatory damages from evi- 
dence related to punitive damages, jurors will hear different instructions than if there had been no bifurcation. Significantly more research has examined the effects of procedural variations on jury damage awards. This research is described in detail below.

\section{Comprehension of Substantive Instructions on Damage Awards}

Critics are quick to point out that jurors misunderstand, misinterpret, and generally mismanage their decision making relevant to damage awards. As one further example, Ellis (1989) argued that the vagueness and uncertainty surrounding punitive damages "invite juries to indulge their biases and penchant for wealth redistribution and induce plaintiffs and their lawyers to seek punitive damages from defendants with deep pockets rather than from morally guilty persons" (p. 979).

Despite such caustic remarks, we have little empirical data on whether jurors correctly interpret and use their substantive instructions on damages. Because the language of these instructions is imprecise and the standards against which to measure comprehension are decidedly ambiguous, little empirical attention has focused on how jurors interpret, comprehend, or apply these admonitions.

This situation is quite different from what we know about comprehension of judicial instructions in criminal cases. In that realm, it is relatively easy to assess whether jurors understand the distinction between different types of offenses, for example, and whether they can apply their knowledge to the facts of a particular case. (Criminal juries are aided in this task by the fact that statutory language rather precisely defines the particular elements they are to consider in reaching a verdict.) Thus, during the 1970s and 1980s, a number of research studies examined jurors' abilities to comprehend and apply criminal jury instructions (Charrow \& Charrow, 1979; Elwork, Sales, \& Alfini, 1977, 1982; Severance, Greene, \& Loftus, 1984). These studies determined that jurors have considerable difficulty understanding pattern instructions adopted from statutory language but that they have more success comprehending, explaining, and using instructions that have been rewritten and simplified using various principles of psycholinguistics. Elwork et al. (1977) found similar patterns of miscomprehension of civil negligence instructions that were ameliorated when the instructions were revised.

Even if courts were receptive to efforts aimed at improving juror comprehension of damage award instructions, the lack of legal standards in this area forecloses easy clarification and simplification. Revised civil jury instructions may be hard to sell because if properly written, they force courts and lawyers to confront the meaning of legal doctrines, which have been, to the present, largely unconfronted.

What (little) do we know, then, about jurors' abilities to understand judicial instructions relevant to damage awards? Aside from anecdotal reports, we know almost nothing about whether jurors comprehend these instructions. One exception to this dearth of data stems from a brief questionnaire study that was conducted as part of a larger study on the effects of bifurcating punitive damages on jurors' decision making (Landsman, Diamond, Dimitropoulos, \& Saks, 1998). These researchers gave mock jurors four multiple-choice questions related to comprehension of their jury instructions to assess the impact of deliberation and bifurcation on jurors' comprehension levels. Deliberations resulted in a slight but significant increase in understanding of 
considerations relevant to compensatory damages, and overall, jurors were quite accurate (approximately 90\% postdeliberation) in their understanding of the components of compensatory damages.

Another recent study (Hastie, Schkade, \& Payne, 1998) has also assessed comprehension of judicial instructions related, in particular, to liability for punitive damages. Mock jurors in this study were given summaries of previously decided cases as well as a comprehensive instruction that set out factors they were to consider in determining whether a defendant's conduct was reckless enough to warrant punitive damages. The instructions provided detailed standards for assessing whether the defendant acted with reckless disregard, included definitions of malicious conduct and reckless and callous disregard for others, and specified the differences between negligent and reckless conduct.

After rendering a judgment about the defendant's liability for punitive damages, participants were asked specific questions on each important element on their instructions (e.g., "What is the legal definition of reckless or callous disregard for the rights of others?"). Hastie et al. (1998) determined that comprehension was very low: the median score was 5\% correct. (Contrast this with the $90 \%$ comprehension described by Landsman et al., 1998. This discrepancy is undoubtedly a result of the questioning procedures: Jurors in Hastie's study were asked to recall elements of the instructions and Landsman's participants were given a recognition [multiple-choice] test.)

Aside from these findings, we know little about jurors' ability to understand the language and directives contained in instructions related to damage awards. No data exist on whether jurors understand that they are to reduce their awards to present value to reflect the fact that the plaintiff should be able to invest the award to cover projected expenses. No data exist on whether jurors comprehend that the standard of proof for proving compensatory damages (i.e., by a preponderance of evidence) may be different from the standard for proving punitive damages (i.e., in some states, by clear and convincing evidence; in Colorado, by evidence beyond a reasonable doubt). Related research by Kagehiro and Stanton (1985) has suggested that jurors have difficulty differentiating among legal standards of proof.

\section{Application of Substantive Instructions Related to Damage Awards}

We do have data relevant to the question of how jurors use (or perhaps misuse) instructions on damage awards, however. In this vein, researchers have attempted to determine if jurors apply their instructions as the law-however vaguely stated - intends or whether, instead, jurors misapply the judge's directives. We have evidence of both outcomes: Some studies have shown that jurors properly use the evidence as directed by the judge, and other studies have found that jurors fail to systematically consider the relevant evidence or that they use it in improper ways.

Evidence showing that jurors correctly apply instructions related to damages. A number of studies show that jurors use relevant evidence in their assessments of damages. A study conducted by Cather, Greene, and Durham (1996) challenged the contention that jurors misapply their instructions on compensatory and punitive damages. This study assessed whether jury damage awards were influenced by legally rele- 
vant considerations (e.g., whether the compensatory damage award was related - as it should be - to the severity of the plaintiff's injury and whether the punitive damage award was related - as it should be - to the reprehensibility of the defendant's conduct) or whether damage award decisions were affected by legally inappropriate criteria (e.g., whether the compensatory damage award was also related to the reprehensibility of the defendant's conduct and whether the punitive damage award was also influenced by the severity of the plaintiff's injury).

Mock jurors in this study read trial transcripts from three cases (automobile negligence, product liability, and insurance bad faith) in which both compensatory and punitive damages could be awarded. The transcripts manipulated the severity of the injury to the plaintiff and the reprehensibility of the defendant's conduct. Jurors were informed that liability had been decided in favor of the plaintiff and that their task was to determine if damage awards were warranted and, if so, in what amount. They received Colorado Civil Jury Instructions outlining the legal determinants of both compensatory and punitive damages. Results of the study show that with one exception (surprisingly, jurors did not award higher compensatory awards to more seriously injured plaintiffs), they attended to legally relevant considerations: Jurors did levy higher punitive awards against highly reprehensible defendants, they did not inflate punitive damage awards for more severely injured plaintiffs, and their decisions about compensation were not influenced by the reprehensibility of the defendant's conduct. Overall, these data suggest that jurors' decisions about damages were indeed influenced by legally relevant criteria, as outlined in their jury instructions.

The law intends that more severely injured plaintiffs will receive more compensation, and, in general, jurors abide by this principle. For example, Taragin, Willet, Wilczek, Trout, and Carson (1992) found that although the severity of the plaintiff's injury was not related to the likelihood of that plaintiff prevailing on liability, it was strongly correlated with the damage award for those plaintiffs who did prevail. Bovbjerg, Sloan, and Blumstein (1989) determined that the "best available single predictor of award amount is the severity of the injury" (p. 920). Bornstein (1998) also found that more severely injured plaintiffs received more compensation. At least in this domain, jurors generally apply their instructions as the law anticipates. ${ }^{2}$

In another study, Greene, Woody, and Winter (2000) assessed whether jurors appropriately apply instructions related to punitive damages considerations. In particular, jurors are to use evidence related to the reprehensibility of the defendant's conduct and the defendant's wealth only to gauge the amount of punitive damages and are not to use this information to determine compensatory damages. Some commentators have suggested that jurors will augment compensatory awards when they know that the defendant is wealthy, when they learn of the defendant's egregious conduct, or in both cases (Ghiardi \& Kircher, 1995; Mogin, 1998).

\footnotetext{
${ }^{2}$ We suspect that our anomalous finding (that more severely injured plaintiffs were not awarded higher compensatory damages) can be explained by the fact that they were awarded more total damages (compensatory plus punitive) than their less-seriously injured counterparts.
} 
Mock jurors in the Greene, Woody, and Winter (2000) study read summaries of three cases: automobile negligence, products liability, and medical malpractice. In each case, the conduct of the defendant (mildly reprehensible vs. highly reprehensible) and the defendant's wealth (moderately wealthy vs. very wealthy) were manipulated.

Did jurors apply their instructions properly? Did they consider only legally relevant criteria and ignore the legally irrelevant? In general, the answer is yes. Evidence about both the defendant's reprehensibility and his wealth influenced punitive damages but not compensatory damages. Jurors assessed higher punitive damages against the highly reprehensible defendant and against the very wealthy defendant, relative to their less extreme counterparts. There were no differences in compensatory awards as a function of either of these manipulations, however. Bornstein (1994) also found that a large corporation was not made to pay more in compensation than a small, independently owned company.

Evidence showing that jurors misapply their instructions related to damages. Unfortunately, the sanguine outlook on jurors' use of damages evidence is tempered by studies showing that jurors also misuse evidence in their damages calculations. Comparative negligence cases pose particular difficulties for jurors, and recent studies show that damage awards in these cases can be errant and unpredictable (see Wissler, Fowler, \& Saks, 2000).

Misapplication of civil jury instructions extends beyond comparative negligence cases. Despite instructions to the effect that liability for damages is determined solely by causation (i.e., the plaintiff is not entitled to receive monetary damages unless he can prove that the defendant caused the injury), mock jurors improperly fuse evidence of the plaintiff's injury severity with their determination of liability for damages (Bornstein, 1998; Greene, Johns, \& Bowman, 1999). So, for example, jurors are more likely to find the defendant liable when the plaintiff has been severely injured than when the injuries are less serious. Interestingly, this effect essentially disappears in situations in which jurors are unable to award damages, leading Bornstein to conclude that jurors' liability judgments are motivated by the desire either to compensate the plaintiff or to punish the defendant. Regardless of the specific motivation, Bornstein's study makes clear that jurors' reasoning extends beyond factors prescribed by the jury instructions.

Both lack of use and misuse of judicial instructions have been noted on another damages-related issue. Hastie et al. (1998) analyzed the content of jury deliberations on liability for punitive damages in cases in which appellate and trial judges had concluded that such damages were not warranted. Although $67 \%$ of juries (excluding hung juries) concluded that punitive damages were warranted, juries were less likely to award punitive damages if someone suggested that the judge's instructions be followed. Unfortunately, many jurors paid little heed to their instructions: When asked to justify their verdicts, only half of the jurors said they referred to the instructions.

Misuse of instructions was apparent as well. When someone on the jury commented in deliberation that compensatory damages had already been paid to the plaintiff, the jury was less likely to award punitive damages. Finally, when negligence (relevant to compensatory damages) was discussed, the jury was also less likely to impose punitive damages liability. Apparently, jurors in this study had difficulty sep- 
arating legal concepts that apply to compensatory and punitive decisions and treated them interchangeably.

How do we reconcile the results of these studies? Why do some studies show that jurors correctly apply judicial instructions regarding damages and others show that they do not? It may be that an equity norm is at work in the comparative negligence context but not in the studies by Greene and her colleagues. In other words, jurors may be attempting to restore a sense of justice in comparative negligence cases by penalizing the plaintiff for her involvement in the injury-causing incident. Other researchers (e.g., Hans \& Lofquist, 1992) have shown that jurors are generally skeptical of plaintiff's claims. Thus, when informed that the plaintiff's actions contributed to the accident, jurors may disregard their jury instructions to compensate the plaintiff fully and instead deliver a verdict that incorporates their sentiments about that errant plaintiff. No such contributory negligence was present in Greene's studies.

It is also likely that jurors will, in other circumstances, reason holistically rather than categorically (as their instructions suggest) and base both liability and damages decisions on the totality of the evidence, rather than on discrete sets of legally relevant information. Clearly though, we do not know enough about how jurors use substantive judicial instructions related to damage award determinations. A better understanding of such usage will require considerably more empirical effort.

\section{Procedural Variations in Jury Instructions Related to Damage Awards}

Although only a handful of studies have focused on how jurors understand and apply substantive jury instructions on damages, significantly more work has looked at how procedural variations (and the instructions that follow from those variations) impact jurors' decisions about damage awards. We describe work related to six kinds of procedural instruction issues: (a) preinstruction on damage award decision making, (b) the impact on jurors' decision making of so-called silent instructions (e.g., taxation of damages, the awarding of attorneys' fees, trebling of damages in antitrust cases, judicial additur and remittitur), (c) the separation or bifurcation of evidence related to the parties' liability from evidence related to damages and the bifurcation of punitive damages evidence from evidence on compensatory damages, (d) the use of a special (as opposed to general) verdict forms, (e) the capping of punitive damages, and (f) the use of more detailed instructions on damage awards. All of these process decisions influence the kinds of substantive instructions that jurors will receive and so are relevant to our concerns.

\section{Preinstructions}

Typically, civil jurors hear judicial instructions only at the end of the trial. This procedure requires them to retroactively apply unfamiliar legal concepts to facts they heard days, weeks, or even months before. Increasingly, judges, lawyers, and other commentators (e.g., Prettyman, 1960) have begun to acknowledge the difficulties that this procedure poses for jurors.

Rule 51 of the Federal Rules of Civil Procedure provides for considerable discretion in the timing of jury instructions and allows the judge to instruct the jury before 
closing arguments, after the arguments, or both. Although little case law discusses the propriety of preinstructions, the practice has been generally commended so long as the jury is again fully instructed at the end of the trial. In 1995, the Arizona Supreme Court began to require judges to give jurors both oral and written preliminary instructions that describe what the plaintiff must prove to win, the burdens of proof, and other matters that can reasonably be anticipated, including damages when applicable (Arizona Supreme Court Committee, 1999).

Proponents of preinstructions suggest that because preliminary instructions can provide a legal framework for the case before the evidence is presented, jurors will be more likely to remember and use the evidence appropriately (Schwarzer, 1991). Substantive preinstructions, they argue, guide jurors in determining the facts that satisfy the requirements of proof and effectively focus jurors' attention on legally relevant evidence. Some proponents claim that preinstructions will help jurors to identify personal biases related to the trial and to resist temptations to succumb to these prejudices (Goldberg, 1981). Finally, proponents contend that preliminary instruction may counter jurors' tendencies to decide the outcome of the case before the judge has delivered instructions on the applicable law and may accommodate their natural tendencies to process evidence as they receive it (Schwarzer, 1991).

Critics doubt that preinstructions will improve jurors' decision-making capabilities (Sand \& Reiss, 1985). They argue that such instructions will heighten the propensity for jurors to decide the outcome before hearing all of the evidence and that they will allow jurors to seek trial information that confirms their preconceptions. They also contend that preinstructions will focus all jurors on the same testimony and will decrease jurors' ability to help each other recall trial testimony. One practical matter may militate against widespread acceptance of preinstructions: Judges may prefer to hear the evidence themselves and to study the relevant law before delivering instructions to the jury.

A field experiment conducted in 34 civil trials in Wisconsin circuit courts (Heuer \& Penrod, 1989) examined several of these hypothesized effects. Judges were randomly assigned either to give preliminary instructions prior to the evidence portion of the trial or to withhold such instruction. (It is unclear whether these judges delivered instructions relevant to damages. The list of frequently used instructions that was provided to judges did not include damages considerations, but judges were encouraged to offer any instructions that they believed would help the jury understand its duty and the evidence it was about to hear.) Following the trials, questionnaires were administered to judges, lawyers, and jurors.

Results showed small positive effects of preinstruction. Contrary to proponents' beliefs, preliminary instructions did not assist jurors with recall of the evidence or of the judge's instructions. They also did not reduce jurors' confusion about the trial process. Pretrial instructions did assist jurors in following legal guidelines in their decision making, however. (This result may be especially good news for damage award determinations, as a major concern in that realm is that jurors will step outside the dictates of the law when assessing damages.) These findings, coupled with the absence of negative effects of pretrial instructions, led the authors to argue that this procedure merits serious consideration in other trials.

More germane to damage award instructions, Irwin Horowitz and his colleagues 
have examined the effects of pretrial instructions on jurors' damages assessments in complex cases (Bourgeois, Horowitz, ForsterLee, \& Grahe, 1995; ForsterLee, Horowitz, \& Bourgeois, 1993). Pretrial instructions have been touted for complex cases in which jurors must distinguish among the claims of various plaintiffs regarding the actions of various defendants.

ForsterLee et al. (1993) examined whether substantive pretrial instructions would allow mock jurors in a toxic tort case to assign compensatory damage awards in accordance with the severity of each of several plaintiffs' injuries. They compared compensatory awards issued by jurors who were preinstructed on the elements of compensation to awards given by jurors who were postinstructed. The timing of the instructions significantly affected the amount of compensation awarded and resulted in clearer differentiation among the plaintiffs: When jurors were preinstructed, the most severely injured plaintiff received the highest award and the least severely injured plaintiff received the lowest award. There were no differences in compensatory awards as a function of injury severity for jurors who received posttrial instructions, however. (And, although not significant, the opposite result was hinted at: Postinstructed jurors awarded slightly more to the least severely injured plaintiff than to the most severely injured plaintiff.) These findings suggest that substantive preliminary instructions can result in compensatory damage awards that better reflect the merit of each plaintiff's case.

Bourgeois et al. (1995) determined that preinstruction may indeed lead jurors to search out confirmatory evidence. These researchers examined the effects of pretrial instructions in a trial that favored the plaintiffs and in which higher, rather than lower, awards were expected from jurors who systematically examined the evidence. In fact, preinstructed jurors gave higher awards than other jurors did, possibly because substantive preinstructions alerted them to the kind of evidence that is required to establish monetary damages and because they sought out and found that information during the trial. (Another possibility, of course, is that pretrial instructions allowed them to better comprehend and use the evidence in their verdict determinations.) In complex cases that involve multiple claims and various parties, pretrial instructions on the components of jury damage awards can apparently lead to a proplaintiff bias in the awarding of damages. The American Bar Association's study of jury comprehension in complex cases (ABA, 1990) reported a similar result.

Commentators have hypothesized about both the benefits and costs of providing preliminary instructions related to jury damage awards. And, although we have a hint of their impact from the work of Heuer and Penrod and of Horowitz and his colleagues, several questions remain. Do preinstructions reduce jurors' temptations to rely on their preconceived biases about appropriate compensation? Do they increase or decrease the tendency to decide the outcome of the case before all of the evidence is presented? Are they likely to cause all jurors to focus on the same evidence and ignore other, potentially meaningful testimony? And, most importantly, what effects might preinstructions have in simple (as opposed to complex) tort cases that jurors hear regularly? Will the same benefits and costs inhere when the evidence is not particularly complex and the trial is not lengthy? 


\section{The Impact of Silent Instructions}

Jury instructions often fail to tell jurors the whole truth. Rather, in an effort to rein in jurors' decision making, courts have denied jurors access to certain types of information, including that pertaining to attorneys' fees, taxation of damage awards, insurance carried by the litigants, the potential reductions of damage awards by appellate courts, and the fact that awards in private antitrust lawsuits will automatically be tripled by the court. In essence, jurors have been "blindfolded." The rationale for blindfolding is that (a) the procedure will prevent bias that might be introduced by the undisclosed information, (b) some facts are so complex that they might confuse rather than educate the jury, and (c) certain evidence simply lacks probative value and wastes the jury's time (Diamond \& Casper, 1992).

Evidence from archival studies, posttrial interviews, and mock jury experiments indicates that jurors may take such considerations into account, however (MacCoun, 1993). Sometimes this consideration occurs explicitly. For example, Goodman, Greene, and Loftus (1989) found that when asked about the factors they considered in assessing damages, $20 \%$ of jurors said they considered that attorneys' fees would need to be paid, and $12 \%$ mentioned that the plaintiff would need to pay taxes on the amount awarded in damages. On other occasions, the influence may be indirect and unspoken but may affect jurors' verdict preferences nonetheless. Thus, in the absence of explicit instructions, jurors' assessments of damages are likely to be inconsistent, haphazard, and, on occasion, contrary to the intentions of the law (MacCoun, 1993).

We can only speculate about the extent to which jurors consider other issues on which judges offer no instruction (e.g., the effects of insurance, the taxability of awards). For example, most state courts do not allow an instruction explaining that compensatory damages awarded to a plaintiff in a tort action such as personal injury or wrongful death are generally excluded from income (Faught, 1985). (These awards are seen as restorations of lost capital, and courts have reasoned that tax considerations would result in jury speculation and conjecture.) Lacking adequate data, it is unclear whether jurors would be better off with or without a judicial instruction on the taxability of compensatory damage awards. It seems highly likely, however, that speculation and conjecture are invited when the jury is blindfolded to ways to handle this issue.

The blindfolding issue that has received the most empirical attention is the unspoken trebling of compensatory damages in antitrust cases (Diamond \& Casper, 1992). This information has historically been kept from the jury because of concerns that informed jurors may reduce their assessed award to an amount deemed sufficient to achieve direct compensation to the plaintiff but that this amount may not be sufficient to adequately penalize the defendant. On the other hand, jurors who are unaware of the trebling rule may augment their awards to punish the defendant and deter future conduct. In any event, blindfolding in this context is likely to produce undesired interjury variation. In fact, Diamond and Casper (1992) suggested that both correct and incorrect expectations might lead blindfolded juries astray.

These researchers designed a mock jury study to test the effectiveness of various sets of jury instructions related to blindfolding. In five conditions, jurors were in- 
structed to compensate the plaintiff for any injury caused by the defendant's antitrust violations. (This is the amount that is automatically trebled by the judge.) Diamond and Casper (1992) varied the information that these jurors were given about the consequences of their decision: One group was told that their verdict would be trebled and that they should neither disregard nor consider this information; a second group was told that their verdicts would be trebled and that they should disregard this fact when making their assessments; the third group was told that their verdicts would be trebled and were given an explanation of the trebling provisions in antitrust statutes; a fourth group was not informed of the trebling rule but instead heard that the judge would add an amount for punishment and deterrence, if necessary; and the fifth group received no indication that the judge would add to their damage award. (This is the typical form of instruction in most courts.)

Analysis of the damage awards showed that jurors who were informed about trebling gave lower awards than jurors who were not. Why? Two explanations are viable: either (a) that the trebling information caused jurors to reduce their awards below what they believed would be necessary to compensate the plaintiff and/or (b) that the desire to punish and deter caused jurors not informed of the trebling rule to augment their awards above what they deemed necessary to compensate the plaintiff. Diamond and Casper (1992) were able to disentangle these possibilities by focusing on awards delivered by the group that was given an explanation for trebling. They found that these jurors gave higher awards than did those without an explanation, suggesting that the reduction in awards with trebling information is at least partially related to windfall avoidance and that jurors who understand why the award is tripled are less likely to reduce their verdicts.

How effective, then, are the present instructions related to blindfolding about damage trebling? The most commonly used instruction, which does not mention the trebling provision of the law, makes no attempt to control jurors' punitive impulses or to inform them of the consequences of their decisions (Diamond \& Casper, 1992). As a result, jurors who come to the deliberation table either with no information or with misinformation about the trebling process may lead the group astray. Once the blindfold is removed, jurors' verdicts are likely to be more predictable and to be grounded in appropriate considerations regarding compensation and penalties. We suspect that similar results would be achieved by removing the blindfold on other issues and by conscientiously and clearly informing jurors about heretofore unspoken considerations.

\section{Bifurcation of Evidence of Liability, Causation, and Damages}

Bifurcation - the separation of trial issues for independent evaluation by the jury - prevents evidence that is relevant to one decision (e.g., liability) from prejudicing the jury's determination on other issues (e.g., compensation). In the absence of a bifurcated trial, juries may improperly consider evidence that has no bearing on the decision at hand. Obviously, the structure of the trial (unitary vs. bifurcated) determines the kinds of instructions delivered to the jury.

At least two forms of bifurcation exist. One involves structuring the trial so that evidence regarding the extent of damages is not included in the liability phase of the trial. Here, the jury hears evidence related to liability (and/or causation), is instructed 
on how to resolve those claims, and determines a verdict on those issues before hearing any evidence or instruction relevant to damages. The second involves separation of the compensatory and punitive damages phases of the trial such that evidence relevant to punitive damages (e.g., the defendant's wealth and prior bad acts) is not made known to jurors until after they have determined liability for and assessed compensatory damages. That way, evidence that is legally irrelevant to compensation cannot inappropriately influence that award determination. We first describe empirical research on bifurcation of liability and damages phases and then turn to the work on separation of compensatory and punitive decisions.

Separation of liability and damages phases of the trial. An early study by Zeisel and Callahan (1963) examined the effects of unitary and bifurcated trial proceedings in tort cases in federal courts in northern Illinois. Defendants prevailed in $79 \%$ of bifurcated trials but in only $42 \%$ of unitary trials. Zeisel and Callahan interpreted this difference as indicating that in unitary trials, jurors use evidence about the extent of the plaintiff's losses in making a decision about liability. Thus, the plaintiff is advantaged. In bifurcated trials, where the decision about liability is made before any evidence of damages is presented, this spillover does not occur, thereby advantaging defendants.

Results of this study raise several questions. For example, why does this spillover occur? Casper (1993) correctly noted that the advantages to plaintiffs in unitary trials could be the product of two diverse processes: (a) the increased blame jurors assign to the defendant after hearing about the serious consequences of his actions may spill over and influence thoughts about that defendant's liability and/or (b) evidence about injuries to the plaintiff may cause jurors to lower their standard of proof for the liability judgment to compensate a needy plaintiff. Bornstein (1998) suggested that evidence of serious injury arouses emotions in jurors that are associated with motivations to alleviate the plaintiff's suffering through compensation and to punish the defendant.

Another unanswered question concerns the effects of bifurcation on verdict size. Landsman et al. (1998) noted that without data on the size of jurors' verdicts, it is impossible to assess the overall consequences of bifurcation. They point out that bifurcation may result in fewer plaintiff verdicts but that the size of the remaining judgments against defendants may increase substantially.

Some data on bifurcation and verdict size comes from the work of Horowitz and Bordens (1990). These researchers exposed all mock jurors in a toxic tort trial to the same evidence but varied the structure of the trial and compared verdicts and compensatory damage awards as a function of trial structure. Juries in unitary trials heard all the trial elements before making any decisions, and juries in the bifurcated trials heard evidence about and made decisions about liability before they were given information on damages. Horowitz and Bordens found, surprisingly, that although most unitary juries decided for the plaintiff (and most bifurcated juries voted for the defendant), the average award in a unitary trial was lower than its counterpart in a bifurcated trial.

Jurors who hear evidence about both liability and damages in a unitary trial and who have no explicit instructions to do otherwise apparently use evidence about the plaintiffs' losses to inform both decisions. (Hence, the increased likelihood of a plaintiff's verdict in a unitary trial.) In fact, Horowitz and Bordens (1990) reported that at 
each decision point, juries searched in other areas, especially evidence concerning damages, to buttress their decisions. In a bifurcated trial (or, perhaps, with clear and effective instructions that the decisions are to be made independently), the spillover effect is reduced. Thus, procedural innovations and the instructions that follow from these innovations can have a significant effect on the outcome of a civil trial.

Separation of compensatory and punitive damages phases. In a unitary trial, all the evidence is presented to the jury at one time, and the jury then retires to make several decisions in the same deliberation session. In a bifurcated trial, on the other hand, the presentation of evidence relevant to punitive damages (e.g., about the manufacturer's disregard for public safety and his net worth) is presented if and only if the jury has already found the defendant liable for compensatory damages and has determined what that compensation should be. In this context, bifurcation has been hypothesized to prevent evidence that is only relevant to punitive damages from prejudicing the jury's determination of compensatory damages.

In a recent study (Greene, Woody, \& Winter, 2000) the effects of bifurcation of compensatory and punitive damages evidence were examined. The structure of the trial was manipulated so that jurors in unitary trials heard all of the evidence before assessing compensatory and punitive damages, and jurors in bifurcated trials made judgments of compensatory damages before hearing any evidence related to defendant reprehensibility and wealth.

What effect did this variation in trial structure (and in the resulting jury instructions) have on damage awards? Surprisingly, it had no effect on compensatory awards. In other words, jurors in unitary trials awarded no more in compensatory damages than did jurors in bifurcated trials. They did not increase their compensatory award to reflect a wealthy defendant's ability to pay, for example. This finding suggests that a remedy proposed to alleviate the hypothesized fusion of punitive damages evidence and compensatory damage decision making may be premature. Finally, trial structure had an unexpected effect on punitive damage awards: Punitive damages were higher in bifurcated trials than in unitary trials. We comment on this finding below.

Landsman et al. (1998) also assessed the impact of bifurcation on awards for compensatory and punitive damages. They used a products liability case that featured both sets of claims and addressed several questions about differences between unitary and bifurcated trials: (a) Are jurors differentially likely to find compensatory liability? (b) Do jurors use evidence differently? (c) Do jurors make awards of different sizes? These researchers edited the transcript from an asbestos case and manipulated two variables (trial structure: unitary or bifurcated; and the strength of the plaintiff's case: weak or moderate) to yield four versions. In addition, jurors in the unitary trial heard either low or high net worth information regarding the defendant.

Are jurors differentially likely to find liability for compensatory damages? Apparently they are. Jurors in unitary trials were more likely to find the defendant liable. Despite instructions to the contrary, these jurors apparently made improper use of punitive damages case facts in assessing liability for compensation.

Do jurors in unitary trials award more in compensatory damages? It depends. When the evidence favoring the plaintiff on liability is moderately strong, jurors in 
unitary trials award more in compensation than they do in bifurcated trials. Jurors in the bifurcated trials - who did not hear evidence of the defendant's egregious behavior-awarded the same amount whether evidence of compensatory liability was weak or moderate. This finding suggests that the punitive damages evidence led jurors in at least some cases to respond with higher compensatory awards and further suggests that bifurcation may offer a protective device for defendants.

Surprisingly, a different picture emerges with respect to punitive damages, although the details are consistent with the findings of Greene, Woody, and Winter (2000): Larger awards came from bifurcated juries than from unitary juries. Landsman et al. (1998) offered several theories to explain this apparent reversal of fortune. First, they suggested that in bifurcated trials, the only juries that decide punitive damages are those that favored the plaintiff in the area of compensation. In a bifurcated proceeding, prodefense juries would never get to the punitive damages phases of a trial. In a unitary trial, prodefense jurors who were unable to prevail on compensation can still assert some restraint on the size of the punitive award. This explanation accounts for Landsman et al.'s finding (where juries determined liability as well as damage awards), but it does not explain the augmented punitive damage awards in Greene, Woody, and Winter (2000; where liability was stipulated and only damages were awarded and where jurors did not drop out as the trial proceeded).

A second possibility is related to cognitive overload that attends jurors in a unitary trial. Here, jurors must make decisions on the basis of larger and more complicated sets of evidence. As a result, there may be more confusion and spillover of evidence among unitary jurors than among jurors who receive a bifurcated case. Jurors in a unitary case may use evidence of the plaintiff's injury to augment punitive damage awards.

A final explanation of the augmented punitive damage awards in bifurcated trials is also related to information processing: With bifurcation, evidence of the defendant's wealth and reprehensible conduct is presented closer to the decision point and may therefore be more salient to jurors.

Taken together, these findings suggest a very complicated picture of the interrelationship of compensatory damages evidence, punitive damages evidence, and the role of bifurcation in separating the two. As Landsman et al.'s (1998) data show, bifurcation apparently effects decisions about compensatory and damage award decision making in variable ways.

\section{Special Verdict Forms}

Another change in verdict procedures involves use of special verdict forms in which the judge submits to the jury a series of specific questions relating to the material issues in the case and requires the jury to deliberate and answer each question separately. The judge then applies the law to these findings to decide the case. For example, in a negligence case, the judge might instruct the jury to determine whether the defendant committed the act, whether the act was negligent, whether the act caused harm to the plaintiff, and what damages, if any, should be awarded (Casper, 1993). Rule 49(a) of the Federal Rules of Civil Procedure allows judges in federal court, at 
their discretion, to submit to the jury a series of questions related to discrete issues in the case.

This procedure is quite different from the traditional (or general) verdict in which jurors are given all the evidence and are called on to answer one or two global questions. Of the two procedures, Saltzberg (1993) suggested that "[s]urely it is easier for jurors to understand that they are being asked to decide whether it is more likely than not that the defendant drove through a red light than for them to master the law of negligence and apply it to the facts of a case" (p. 360). General verdicts have been criticized for failing to assist jurors in organizing the evidence and for promoting compromise verdicts in situations in which jurors conflate legally separate issues (Casper, 1993). (For example, in tort cases where the evidence on liability is slightly in favor of the defendant but where the plaintiff has incurred significant injury, the jury may find liability where none exists to be able to assign damages to compensate the injured plaintiff. A general verdict form would not reveal the basis for this sort of verdict.)

As with other proposed reforms, hypothesized effects are many and actual data are few. Special verdict procedures are believed to provide some advantages over the traditional general verdict (Casper, 1993). First, special verdicts may assist jurors in organizing and simplifying their task because such procedures encourage jurors to focus on discrete issues. Second, because fewer difficult legal concepts are conveyed to the jury at any one time, special verdict procedures are expected to result in simplified jury instructions (or, at least, in the appearance of simpler instructions because fewer are presented at one time). Special verdicts may result in fewer compromise verdicts (as, e.g., when the jury decides to find liability in order to award damages) because jurors will be unaware, when making any single decision, about the implications of that decision. In theory, then, they will focus more clearly on the task at hand. Finally, special verdict procedures allow for monitoring of the jury's adherence to the law.

On the other hand, special verdict procedures may have detrimental effects on the reasoning of civil jurors (Casper, 1993). They may, for example, introduce a number of systematic biases into the decision-making process. As the number of issues increases in a special verdict arrangement, chances are that the plaintiff (who bears the burden of proof) may eventually be disadvantaged. On the other hand, if jurors with general verdict instructions focus on whether the conjunction of all issues has been proven, they may be less likely than special verdict juries to find for the plaintiff (Lombardero, 1996). Special verdict questions may, at least in complex cases, involve mixed issues of fact and law and thus be difficult to frame. Finally, narrowing jurors' decision-making powers may reduce their ability to bring a sense of justice or equity to the proceedings.

What do the data tell us about special verdict forms? We could find only three reported studies on these effects. Schmidt and Diamond (1998) examined the effects of verdict forms in a products liability case and found that mock jurors with a general verdict form were nearly twice as likely to favor the plaintiff as those with the special verdict form. These researchers did not assess the effects of special verdicts on the frequency or size of damage awards, however.

Wiggins and Breckler (1990) examined that issue in a defamation case. Mock jurors were given either a general verdict form that asked them simply to find for the 
plaintiff or the defendant and award the appropriate damages or a special verdict form that required them to answer several questions about the case (e.g., "Did the plaintiff prove by a preponderance of the evidence that the defendant made a defamatory statement about her?" "Did the plaintiff prove by a preponderance of the evidence that the defamatory statement injured her?"). Although the verdict procedures (general vs. special) had no effects on liability judgments, mock jurors making special verdicts gave significantly higher compensatory damage awards than those issuing only general verdicts. The effect of attending to multiple and consecutive questions of fact was apparently to make the plaintiff's losses more highly compensable.

A variation of the special verdict form that was used by Zickafoose and Bornstein (1999) calls that finding into question, however. Here, jurors in a mock medical malpractice case were forced either to determine the total damage award first and then divide this amount into its individual components (for medical expenses, lost income, pain and suffering, and the physical injury suffered) or to determine the amounts for individual components before arriving at the total damage award. There were no differences in total award as a function of this variation, suggesting that jurors might not award more simply because their decision is broken down into a number of smaller steps.

Do special verdicts simplify the jury's task by encouraging them to focus on discrete issues? Do they simplify the jury instructions? Are they difficult to write? As before, the data are sketchy and apparently mixed. Judges who have used special verdicts tend to find them helpful but jurors are less sanguine. This suggests that problems with comprehension and organization of the evidence are not necessarily solved by restructuring the jury's task (Casper, 1993). The finding that alterations in verdict procedures can influence the level of damages awarded is an intriguing one and merits further attention.

\section{Capping Damage Awards}

In response to concerns about the variability and size of damage awards, caps or maximum limits on allowable damages have been imposed in a number of states (Saks, Hollinger, Wissler, Evans, \& Hart, 1997). Typically, these caps limit only the size of noneconomic and punitive awards. In the area of punitive damages, caps can consist of an absolute limit, a maximum permitted ratio (i.e., a certain multiple of the compensatory damages), or both. Generally, legislation allows the cap on punitive damages to be exceeded if the defendant's behavior is especially egregious (Koenig \& Rustad, 1993).

Caps have been touted as providing "unmistakable guidance to juries, trial courts and appellate courts" (Crookston v. Fire Insurance Exchange, 1991, p. 809), thereby removing any possibility of wildly excessive awards, informing defendants about the maximum amount they might have to pay, and reducing administrative and litigation costs. Critics contend that caps place artificial limits on the jury's ability to assess awards commensurate with the defendant's behavior, thereby blunting the effect of punitive damages as a weapon of punishment and deterrence and that ratio-based caps dismantle the sting of punitive damages in cases with fortuitously low compensatory awards ("Developments in the Law," 1997).

On occasion, these limits are communicated directly to jurors in the form of ju- 
dicial instructions. For example, the punitive damages instruction in Colorado states explicitly:

If you find ... that the injury complained of was attended by circumstances of willful and wanton conduct, then in addition to actual damages, you may also assess a reasonable sum as exemplary [punitive] damages not to exceed the amount awarded as actual damages. (Colorado Jury Instructions 3d, 1989)

More typically, jurors are not instructed about limits imposed on their decisions. Rather, courts merely impose these limits on any award that exceeds the maximum allowable. Over time, however, some or many members of the jury may become aware of such provisions (Saks et al., 1997), either because they are familiar with local legislative debates that surround this issue or because they have general knowledge about attempts at tort reform. In this light, jurors are again blindfolded: Some of them may come to the deliberation table with a lay understanding of capping provisions but receive no explicit guidance from the judge to support their intuitions.

What effect will awareness of such caps have on jurors awards? Several studies (e.g., Hinsz \& Indahl, 1995; Robbennolt \& Studebaker, 1999; Saks et al., 1997) found that limits serve as anchors to mock jurors' judgments. For example, Saks et al. (1997) examined the effects of capping awards for pain and suffering and found that in cases involving low or moderate injuries, such limits increased both the size and variability of the plaintiff's awards.

Hinsz and Indahl (1995) manipulated the amount of the limit (\$2 million or \$20 million) and the way it was conveyed (either as an absolute limit or as a recommendation) in a videotaped automobile negligence case. They found that when a dollar value was introduced as an anchor, damage awards moved toward the anchor, regardless of its level or whether it was an absolute limit or merely a recommendation.

Other effects of capping damages have been hypothesized. For example, in a recent study (Greene, Coon, \& Bornstein, in press), we suspected that the capping of punitive damages might result in augmented compensatory damages in tort cases. Mock jurors in this study read transcripts from three cases that varied the instructions related to punitive damages. Some participants were told that punitive damages were limited to a set dollar amount $(\$ 200,000)$, some were limited to a ratio of the compensatory award (i.e., not to exceed the compensatory award), some were not limited, and still others did not have an opportunity to award damages. We wondered if, when the defendant's behavior was particularly egregious, jurors with restrictions on their punitive damages decision would augment compensatory damages to reflect a desire to punish and deter. We found no evidence for this effect but did find spillover effects of another sort. Jurors who had no option to award punitive damages returned the highest compensatory damages award of any group, suggesting that some extralegal factors were affecting their damages calculations.

\section{Providing More Detailed Instructions About Damage Awards}

In the area of punitive damages, there has been much clamoring for reform in the way jurors are instructed. Although most commentators agree that punitive damages 
serve valid and compelling state interests and should not be eliminated, there is also significant consensus that clearer guidelines governing jurors' decisions in punitive damages litigation are warranted. A representative commentary:

By forcing defendants to bear the total cost of their misconduct, punitive damages strike a sensible balance between the need to punish and deter aggravated misconduct and the need to encourage competitive and efficient product and service development... . Despite the benefits society can reap from imposing punitive liability, however, continuous unbridled jury discretion in assessing punitive judgments may ultimately cause preventable adverse repercussions. (Perczek, 1993, p. 866)

Criticisms of punitive damages doctrine focus on two instructional issues: determining liability for punitive damages and assessing their amount. On the liability issue, the criticism is that because of the vagueness in standards for determining liability for punitive damages, juries have no legitimate basis for determining whether or not to make such awards and may make this important decision on the basis of passion, bias, and prejudice. Data from Hastie et al. (1998) showing that jurors fail to systematically consider the full set of conditions necessary to impose punitive damages support this concern.

Can the vagueness inherent in these instructions be reduced, and can jurors be given more specific guidance about when the imposition of punitive damages is appropriate? This would be a difficult task, indeed. Although the formulation of definitive standards for punitive damages can perhaps be improved (e.g., by using consistent standards of defendant misconduct and burden of proof across jurisdictions), the nature of misconduct is such that it will probably always remain unsusceptible to precise definition (Owen, 1994).

A related criticism is that current instructions give jurors little guidance about how much to award in punitive damages: "The jury is given no guidepost with which to measure whether 1 million or 100 million dollars is the appropriate punishment... . These sort of general instructions are little better than advising the jury to 'do the right thing' " (Melsheimer \& Stodghill, 1994, p. 337). Again, the concern is that without clearer standards for determining the proper amounts of such awards, the jury is invited to render its verdict in excessive amounts based on passion and prejudice (Owen, 1994).

There is, in fact, significant variation in the instructions juries receive relevant to award amounts. For example, although most courts permit the plaintiff to prove the extent of the defendant's wealth, some states (e.g., California) require it, and at least one state (e.g., Colorado) specifically forbids the introduction of this evidence. Juries assessing punitive damages in these various states will obviously do so in quite different ways and may, as a result, reach quite different conclusions.

Is it possible to reduce the vagueness inherent in determining the amount of punitive damages? Although individual states typically desire autonomy on these issues, the use of evidence about defendant wealth and the imposition of limits on punitive damages could be made more consistent across jurisdictions. Because of the very real problems in finding a widely accepted basis for determining the proper amount of a punitive damages award, however, there will be no entirely satisfactory answer to this concern.

Some commentators, unwilling to accept the vagueness inherent in the current 
system, have proposed various revisions to judicial instructions on punitive damages. For example, Perczek (1993) has offered a sample jury instruction that she claims will limit discretion and provide appropriate guidance to the jury in punitive damages cases. Excerpts of the instruction are as follows:

Punitive damages are damages exceeding the amount of money necessary to compensate the plaintiff for his/her injury and loss. You may award punitive damages for two purposes only: to punish the defendant for his/her willful conduct or conduct evincing a reckless disregard for probable consequences and to make him/her an example so as to warn and deter others from engaging in similar misconduct. ... In deciding whether to award punitive damages, you must consider the following factors: 1) the degree of reprehensibility of the defendant's conduct and the grievousness of his/her acts; 2) the duration of that conduct and the degree of the defendant's awareness that the conduct would harm the plaintiff; 3) the attitude and conduct of the defendant upon discovery of his/ her misconduct and any actions taken by the defendant to remedy the misconduct once it became known to him/her; 4) the defendant's concealment; and 5) the existence and frequency of similar misconduct in the past. ... There are certain factors that will aid you in determining the amount of punitive damages ... and you must consider them in deciding a just and fair amount. ... You must consider the following: 1) the likelihood, at the time of the defendant's misconduct, that serious harm would result from it; 2) the seriousness of the hazard to the public arising from the defendant's misconduct; 3 ) the duration of that hazard and its excessiveness; 4) the profitability of the misconduct to the defendant; 5) the desirability of removing that profit from the defendant. ... There is one last factor that you may consider in assessing the punitive damages award, and that is the defendant's wealth and financial condition. You have heard evidence pertaining to the defendant's wealth and financial condition. This evidence was admitted for your consideration only with reference to the question of what amount of punitive damages is necessary to punish the defendant in view of his/her financial condition. (pp. 868-872)

Finally, the Model Punitive Damages Act (1996) lists a number of factors that reformers believe are relevant to jury decisions about punitive damages and that judges should deliver in these cases. Among the factors are the following:

1. The nature of the defendant's wrongful conduct and the effect on the claimant and others

2. The amount of compensatory damages awarded

3. Fines, penalties, damages or other restitution to be paid by the defendant arising from this wrongful conduct

4. The defendant's present and future financial condition and the effect of the award on these conditions

5. Any profit or gain obtained by the defendant through his wrongful conduct

6. Any adverse effect of the award on innocent persons

7. Any remedial measures taken or not taken by the defendant since the wrongful conduct

8. Any compliance or noncompliance with applicable standards governing these actions

9. Any other aggravating or mitigating factors relevant to the amount of the award

Clearly these proposed instructions provide more specific guidelines than present 
directives. But are they comprehensible? Jurors who hear these proposed instructions will be required to understand and use esoteric terms such as evincing, claimant, and grievousness, which are not part of the vernacular of the layperson. So, it is an empirical question to what extent these revisions will help. Will consideration of these factors cabin jurors' discretion and result in more predictable awards? Or will such a lengthy list give jurors permission to consider a wider range of factors and ultimately result in more disparate verdicts and awards? Are the revised instructions likely to enhance juror comprehension if they still contain unfamiliar and complicated terminology? Because neither proposed instruction has been evaluated empirically, we can only guess at its effectiveness.

\section{Conclusion}

When assessing whether a civil defendant is liable for damages and in what amount, jurors must make several difficult, subjective decisions about uncertain circumstances. To assist them in this task, the trial judge typically delivers a set of directives that casts only faint light on the jury's assignment. We should not be surprised, then, by jurors' occasional or even frequent failings to do the right thing - to attend to relevant evidence only, to disregard irrelevant evidence, to properly separate legally discrete concepts, and to reason on the basis of knowledge rather than passion or prejudice. But neither should we chastise jurors for their missteps. Studies of the effects of procedural variations in damage award decision making suggest that jurors can be assisted in a variety of ways by reforms at the trial level. We know, for example, that jurors' determinations of damages could be assisted by preinstructions and by removing the blindfold on various provisions of damages doctrine. We know that bifurcation and special verdict forms may be helpful in certain circumstances. We also know that at least one proposed reform may actually be counterproductive: Caps on punitive damages increase both the size and variability of jury awards. And finally, although we lack good data on this point, revision and clarification of the judge's instructions on damages might have sanguine effects on jurors' and juries' decisions.

\section{References}

American Bar Association. (1990). Jury comprehension in complex cases. Washington, DC: Author.

Arizona Supreme Court Committee. (1999). Jurors: The power of 12. Tucson, AZ: Author.

Bornstein, B. (1994). David, Goliath, and Reverend Bayes: Prior beliefs about defendants' status in personal injury cases. Applied Cognitive Psychology, 8, 233-258.

Bornstein, B. (1998). From compassion to compensation: The effect of injury severity on mock jurors' liability judgments. Journal of Applied Social Psychology, 28, 1477-1502.

Bourgeois, M., Horowitz, I., ForsterLee, L., \& Grahe, J. (1995). Nominal and interactive groups: Effects of preinstruction and deliberations on decisions and evidence recall in complex trials. Journal of Applied Psychology, 80, 58-67.

Bovbjerg, R., Sloan, F., \& Blumstein, J. (1989). Valuing life and limb in tort scheduling "Pain and suffering." Northwestern Law Review, 83, 908-960. 
Browning-Ferris Industries, Inc., v. Kelco Disposal. Inc. 492 U.S. 257 (1989).

Casper, J. (1993). Restructuring the traditional civil jury: The effects of changes in composition and procedures. In R. Litan (Ed.), Verdict: Assessing the civil jury system (pp. 414 459). Washington, DC: The Brookings Institution.

Cather, C., Greene, E., \& Durham, R. (1996). Plaintiff injury and defendant reprehensibility: Implications for compensatory and punitive damage awards. Law and Human Behavior, 20, 189-205.

Charrow, R., \& Charrow, V. (1979). Making legal language understandable: A psycholinguistic study of jury instructions. Columbia Law Review, 79, 1306-1374.

Colorado Supreme Court Committee on Civil Jury Instructions. (1989). Colorado Jury Instructions 3d: Civil. San Francisco: Bancroft-Whitney Co.

Crookston v. Fire Insurance Exchange. 817 P.2d 789 (1991)

Developments in the law: The civil jury [Note]. (1997). Harvard Law Review, 110, $1408-1536$.

Diamond, S. (1993). What jurors think: Expectations and reactions of citizens who serve as jurors. In R. Litan (Ed.), Verdict: Assessing the civil jury system (pp. 282-305). Washington, DC: The Brookings Institution.

Diamond, S., \& Casper, J. (1992). Blindfolding the jury to verdict consequences: Damages, experts and the civil jury. Law and Society Review, 26, 513-563.

Ellis, D. (1989). Punitive damages, due process, and the jury. Alabama Law Review, 40, 975-1002.

Elwork, A., Sales, B. D., \& Alfini, J. J. (1977). Juridic decisions: In ignorance of the law or in light of it? Law and Human Behavior, 1, 163-190.

Elwork, A., Sales, B. D., \& Alfini, J. J. (1982). Making jury instructions understandable. Charlottesville, VA: Michie.

Faught, H. (1985). Instructing the jury on the taxability of their awards - but first, how are they taxed? American Journal of Trial Advocacy, 9, 299-317.

ForsterLee, L., Horowitz, I., \& Bourgeois, M. (1993). Juror competence in civil trials: The effects of preinstruction and evidence technicality. Journal of Applied Psychology, 78, $14-21$.

Ghiardi, J., \& Kircher, J. (1995). Punitive damages law and practice. Deerfield, IL: Clark, Boardman and Callaghan.

Goldberg, J. (1981). Memory, magic, and myth: The timing of jury instructions. Oregon Law Review, 59, 451-475.

Goodman, J., Greene, E., \& Loftus, E. (1989). Runaway verdicts or reasoned determinations: Mock juror strategies in awarding damages. Jurimetrics Journal, 29, 285-300.

Greene, E., Coon, D., \& Bornstein, B. (in press). The effects of limiting punitive damage awards. Law and Human Behavior.

Greene, E., Johns, M., \& Bowman, J. (1999). The effects of injury severity on jury negligence decisions. Law and Human Behavior, 23, 675-693.

Greene, E., Johns, M., \& Smith, A. (in press). The effects of defendant conduct on jury damage awards. Journal of Applied Psychology. 
Greene, E., Woody, W. D., \& Winter, R. (2000). Compensating plaintiffs and punishing defendants: Is bifurcation necessary? Law and Human Behavior, 24, 187-205.

Hans, V., \& Lofquist, W. (1992). Jurors' judgments of business liability in tort cases: Implications for the litigation explosion debate. Law and Society Review, 26, 85-115.

Hastie, R., Schkade, D., \& Payne, J. (1998). A study of juror and jury judgments in civil cases: Deciding liability for punitive damages. Law and Human Behavior, 22, 287-314.

Heuer, L., \& Penrod, S. (1989). Instructing jurors: A field experiment with written and preliminary instructions. Law and Human Behavior, 13, 409-430.

Hinsz, V., \& Indahl, K. (1995). Assimilation to anchors for damage awards in a mock civil trial. Journal of Applied Social Psychology, 25, 991-1026.

Horowitz, I., \& Bordens, K. (1990). An experimental investigation of procedural issues in complex tort trials. Law and Human Behavior, 14, 269-285.

Kagehiro, D., \& Stanton, W. (1985). Legal vs. quantified definitions of standards of proof. Law and Human Behavior, 9, 159-178.

Koenig, T., \& Rustad, M. (1993). The quiet revolution revisited: An empirical study of the impact of state tort reform of punitive damages in products liability. The Justice System Journal, 16, 21-44.

Landsman, S., Diamond, S., Dimitropoulos, L., \& Saks, M. (1998). Be careful what you wish for: The paradoxical effects of bifurcating claims for punitive damages. Wisconsin Law Review, 1998, 297-342.

Lombardero, D. (1996). Do special verdicts improve the structure of decision making? Jurimetrics, 36, 275-324.

MacCoun, R. (1993). Inside the black box: What empirical research tells us about decision making by civil juries. In R. Litan (Ed.), Verdict: Assessing the civil jury system (pp. 137180). Washington, DC: The Brookings Institution.

Melsheimer, T., \& Stodghill, S. (1994). Due process and punitive damages: Providing meaningful guidance to the jury. Southern Methodist University Law Review, 47, 329-350.

Model Punitive Damages Act. (1996). Uniform law commission. Accessible online: http://www.lectlaw.com/files/leg19.htm

Mogin, P. (1998). Why judges, not juries, should set punitive damages. University of Chicago Law Review, 65, 179-224.

Owen, D. (1994). A punitive damages overview: Functions, problems, and reform. Villanova Law Review, 39, 363-413.

Perczek, J. (1993). On efficiency, punishment, deterrence, and fairness: A survey of punitive damages law and a proposed jury instruction. Suffolk University Law Review, 27, 825-904.

Prettyman, E. (1960). Jury instructions-First or last? American Bar Association Journal, 46, 1066.

Robbennolt, J., \& Studebaker, C. (1999). Anchoring in the courtroom: The effects of caps on punitive damages. Law and Human Behavior, 23, 353-373.

Saks, M., Hollinger, L., Wissler, R., Evans, D., \& Hart, A. (1997). Reducing variability in civil jury awards. Law and Human Behavior, 21, 243-256. 
Saltzberg, S. (1993). Improving the quality of jury decision making. In R. Litan (Ed.), Verdict: Assessing the civil jury system (pp. 341-377). Washington, DC: The Brookings Institution.

Sand, L., \& Reiss, S. (1985). A report on seven experiments conducted by District Court judges in the second circuit. New York University Law Review, 60, 423-497.

Schmidt, E., \& Diamond, S. (1998). Controlling the jury by structuring the jury's task. Paper presented at the meeting of the American Psychology-Law Society, Redondo Beach, CA.

Schwarzer, W. (1991). Reforming jury trials. Federal Rules Decisions, 132, 575-596.

Severance, L., Greene, E., \& Loftus, E. (1984). Toward criminal jury instructions that jurors can understand. Journal of Criminal Law and Criminology, 75, 198-233.

Taragin, M., Willet, L., Wilczek, A., Trout, R., \& Carson, J. (1992). The influence of standard of care and severity of injury on the resolution of medical malpractice claims. Annals of Internal Medicine, 117, 780-784.

TXO Production Corp. v. Alliance Resources Corp. 509 U.S. 443 (1993).

Vidmar, N. (1995). Medical malpractice and the American jury. Ann Arbor, MI: University of Michigan Press.

Wiggins, E., \& Breckler, S. (1990). Special verdicts as guides to decision making. Law and Psychology Review, 14, 1-41.

Wissler, R., Evans, D., Hart, A., Morry, M., \& Saks, M. (1997). Explaining "pain and suffering" awards: The role of injury characteristics and fault attributions. Law and Human Behavior, 21, 181-207.

Wissler, R., Fowler, P., \& Saks, M. (2000). Instructing juries on noneconomic damages: Problems and possibilities.. Psychology, Public Policy, and Law, 6, 712-742.

Zeisel, H., \& Callahan, T. (1963). Split trials and time saving: A statistical analysis. Harvard Law Review, 76, 1606-1625.

Zickafoose, D., \& Bornstein, B. (1999). Double discounting: The effects of comparative negligence on mock juror decision making. Law and Human Behavior, 23, 577-596. 